\title{
The Mind-Technology Problem
}

\author{
Steve Fuller ${ }^{1}$
}

Accepted: 6 March 2021 / Published online: 29 March 2021

(c) The Author(s) 2021

Keywords Mind-technology $\cdot$ Humanity $\cdot$ Variable $\cdot$ Constant $\cdot$ Cyborg $\cdot$ Philosophy of technology $\cdot$ Epistemology $\cdot$ Ontology $\cdot$ Ethics

\section{Humanity as a Constant vs. Humanity as a Value of a Variable}

Clowes, Gärtner and Hipolito (2021) have recently introduced the mind-technology problem. It is a legitimate metaphysical rival to the 'mind-body problem' because 'humanity' is a deeply vague concept. It is 'vague' in two senses: the set of qualities associated with being human is open-ended and the set of beings to which human qualities apply is equally open-ended. Of course, not everyone seems to believe this. Indeed, a broad church of natural law theorists, phenomenologists and evolutionary psychologists - who agree on little else-believe that humanity can be identified with the biological species Homo sapiens, whose brains have remained largely the same for the past 40,000 years, resulting in a robust conception of 'human nature' captured, for examples, as 400 + cross-cultural 'human universals' in the Appendix to Pinker (2002). More generally, this view is represented by such unlikely fellowtravellers as Hubert Dreyfus, John Searle and Luciano Floridi. These philosophers appear to have strong intuitions of what is and is not 'human', on the basis of which they conclude, for example, that machines cannot be intelligent, we are not cyborgs, only humans are entitled to rights, etc.

However, their vision of 'human nature' is pure syncretism. It is a pastiche of the mid-eighteenth-century European imagination updated for today. The specific identification of humanity with the upright ape Homo sapiens dates only to Carolus Linnaeus' (1759) famed System of Nature. He tried to translate Christian creationist sensibilities into fashionably naturalistic terms, but at the cost of leaning heavily on a species essentialism traditionally rooted in Aristotle that was already beginning to fall out of favour among natural historians. In particular, species essentialism was being impressively contested in Linnaeus' day by Count Buffon, whose belief in life as a continuum revived a Neo-Platonic sensibility about the 'communication of

Steve Fuller

s.w.fuller@warwick.ac.uk

1 University of Warwick, Coventry, UK 
forms' (Lovejoy 1936) that was subsequently inherited by both Lamarck and Darwinat least as of the fourth edition of Origin of Species (1866), when he finally had read Buffon! Indeed, the family of thinkers in the modern era called 'evolutionists', who differed considerably over the means and ends of such 'evolution', have nevertheless shared a 'continuist' turn of mind that tends to reduce differences of kind to differences of degree.

I credit this insight to Charles Sanders Peirce, whose own thinking had been energized by John Duns Scotus' opposition to Thomas Aquinas. To cut a long medieval story short, the Scotist idea is that the nature of something is established at the moment of identification (Kripkean 'naming' is today's version), which amounts to saying 'that it is' (haecceitas) rather than 'what it is' (quidditas). The latter is simply the possible train of consequences that follow from that initial naming exercise. At stake in the original medieval context was the sense in which 'humans' (understood vaguely) are still created 'in the image and likeness of God', given a general understanding of humanity's 'fallen' nature. Wherein lies our divine liability? Are we 'Godlike' in that we enjoy the deity's linguistic creativity (logos), which enables us to name as we please but without necessarily knowing all the consequences of that which we have named (Scotus)? Or, are we 'God-like' in that we can know all that the deity has created, but without our own words having anything like divine efficacy (Aquinas)?

A measure of modernity's Scotist turn is that humanity has become increasingly comfortable with existing in a 'variable' state of being, which I shall make more precise shortly. Instead of the Thomist eternal verities that are enshrined in 'natural law', which command scientific and political obedience, ours is a succession of temporary pseudo-deities rolling out in real time, whose legitimacy can be overturned by the next experiment or next election, collectively testing the boundaries of what 'humanity' can be. To be sure, both forms of self-understanding are 'realistic' in the sense that normally concerns psychiatrists. However, the former presumes that the will should conform to the intellect, whereas the latter presumes vice versa. Of course, these respective strategies may come to please or disappoint their holders, depending on their overall spiritual disposition. Moreover, it remains an open question the extent to which Thomist and Scotist 'humans' can peacefully and productively coexist. History presents a mixed picture.

The question ultimately turns on how literally one takes St Augustine's strikingly dualistic approach to time in the Confessions (397-400) and the City of God. (426). Augustine's premier intellectual concern-befitting a high-ranking official in the early Christian church - is the calibration of how God sees humanity as a whole and how 'we' as extended moments of humanity see God. The main source of incommensurability in the two understandings is that God knows always and at once what we only discover partially over time, with all the liabilities that entails for us. To be 'human' in this sense is to be suspended between the eternal and temporal. A good modern way to see this point that has legal and political import is to consider the difference between freedom and liberty. 'Freedom' simply implies release from a dominant party (e.g. a slave master), whereas 'liberty' implies self-determination with impunity. The human condition exists between these two unbounded states of being. In this context, 'autonomy' has been about reconciling the two ideas through 'self-legislation' à la Stoics and Kant. It is captured well by the metaphysical phrase 
'free will', which implies doing more than we have without exceeding what we can do. Thus, Kant declared, 'Ought implies can'. Or, to recall Quine (1948), what does it mean to be a value in a bound variable?

Quine's famous ontological slogan enables us to circle back to his fellow mathematician Peirce. Mathematically speaking, there are three ways of thinking about the nature of humanity. It might be seen as a constant, a variable or a value of a variable. Those who extol and decry that ours is the 'Anthropocene' split the difference between seeing humanity as a constant and as a value of a variable. On the one hand, ultra-humanists see our species as coming into self-consciousness as we increasingly reorient the Earth towards ourselves, as if humanity were a biological version of the solar deity so admired by Copernicus and Kepler. The heretical Jesuit scientist Pierre Teilhard de Chardin coined the term 'hominization' to describe the process, and it attracted the interest of such forgers of the modern evolutionary synthesis as Julian Huxley and Theodosius Dobzhansky. On the other hand, the anti-humanists see Homo sapiens in terms arguably truer to Darwin himself-namely, as merely one among many extended moments in natural history that will last only as long as it stays within certain material parameters, aka 'selection environment'.

\section{'Humanity' as the Name of a Variable}

These two contrasting positions have solidified over the past quarter-century as rival ideologies: transhumanism and posthumanism. For transhumanists, the Anthropocene marks our species launch into a kind of biological immortality through our outright mastery of the processes of creation. For posthumanists, it constitutes our species death sentence, since the only thing immortal about us is our genes, as Richard Dawkins would say-or our 'germ plasm', to recall the phrase used by August Weismann a century earlier to make the same point, but with greater metaphysical self-awareness. To be sure, such opposing intuitions about the fate of humanity are clearest among those who accept the Linnaean equation of 'human =Homo sapiens'. However, there remains the middle position, which the mind-technology problem encapsulates. It consists in exploring what it might mean for 'humanity' to name a variable.

Thinking of humanity as a variable stays true to the concept's deep vagueness. Equally, it does justice to both pre- and post-Linnaean intuitions about the nature of humanity, where 'pre-Linnaean' means the theological conception of the human found in Augustine and Scotus, and which Peirce can be seen as having revived in secular guise. It takes the 'human' to name primarily a relationship to God-or the 'Absolute', in Peirce's more neutral terms - that Augustine expressed in terms of the two incommensurable temporal horizons sketched above. As vividly illustrated in St Francis of Assisi's 'communion with nature', such an extended sense of humanity included the 'humane' treatment of animals and nature more generally. By 'postLinnaean', I mean the fascination that transhumanists and posthumanists share for the radical technological transformation of the human condition that has resulted in cyborgs as 'hopeful monsters' that are in some sense 'evolutionary descendants' of Homo sapiens. In this context, trans- and post-humanists differ in that the former see 
cyborgs as simply humans with a substrate upgrade, whereas the latter see them as a separate species from humans. This difference in turn corresponds to their respective optimistic and pessimistic future visions of Homo sapiens.

Before delving further into this cyborg vision of humanity, for which the term 'fluid' might be more appropriate than 'hybrid' (pace Donna Haraway), it is worth noting that the Linnaean equation has been central to anchoring modern normative intuitions of individual accountability and responsibility in ethics, politics and the law. Simply put, Linnaeus may have himself stressed that the upright ape had a soul, but what really mattered to moderns was that each soul was effectively encased in a discrete physical body, which in turn made it easier to track the course of action both out of and back to specific humans. Considering that throughout most of history, and in virtually all cultures, one's permissible sphere of activity has been defined by the kind of person one is, the idea that, on a general basis, individuals might be judged exclusively in terms of what they themselves are determined to have done served to render the courtroom closer in spirit to the context in which divine judgement supposedly occurs. Indeed, the two main modern normative schools-Kantianism and Utilitarianism-presuppose just such an arrangement, with Kantians judging an individual's action before and Utilitarians after it happens, but both confident that the individual's specific causal contribution to a target state of the world can be ascertained, be it imaginatively (à la Kant's categorical imperative) or empirically (à la Bentham's legislative science).

Of course, some philosophers, notably G. E. Moore in Principia Ethica (1903), have contested the fundamental plausibility of this general line of thought as a basis for the normative order. However, these critiques have tended either to focus on the conceptual and practical difficulties in following Kant's or Bentham's advice or to deny their shared belief in the primacy of human agency in determining the normative order. However, the recent arrival of trans- and post-humanism goes one crucial step further. These two movements function as a pincer attack, the effect of which is to seriously erode the intuitiveness of the Linnaean equation on its own termsby which I mean the ontological boundaries of the 'human', understood as a standalone being who is accountable and responsible for its actions. This is the context in which we should start taking seriously the idea of the cyborg as a kind of 'Humanity 2.0' (Fuller 2019: Chap. 2). We might also add so-called 'mind-clones' that begin life as digitally uploaded versions of human minds but then acquire their own independent cyber-existence, which diverge significantly over time from their originating brains. Both prospects are discussed in this volume, but in what follows I shall focus on cyborgs, since they retain a substantial connection to their Homo sapiens origins.

\section{The Cyborg as the Variable Human}

One rearguard argument, nowadays associated with Floridi (2014), needs to be put to rest. It concludes that conceptions of the mind change but the mind itself remains unchanged. This only makes sense if the mind is identified with the human brain, which begs the question in favour of the Linnaean equation. However, if the identity 
of the human is presumed to be only contingently or partially captured in the upright ape, then the distinction between the mind and its conceptions loses salience. Thus, the physically distributed conception of the mind associated with, say, Andy Clark's (2004) version of the cyborg may constitute a superior version of humanity vis-à-vis the version whose mind is confined to an upright ape body. To be sure, this view is relatively alien to the philosophy of mind, and the transhumanist term 'enhancement' fudges the issue at stake, as it can be understood to mean simply something that is auxiliary to our 'core' mental capacities. However, smartphones do more than merely extend already existing human capacities: They facilitate the redistribution of those capacities across distinct physical entities-namely, the upright ape and the rectangular phone. Something that might be called 'cognitive enhancement' is the overall effect of that redistribution. In this and other related respects, the law can provide much needed clarity to the situation. Thus, in the 2014 US Supreme Court case Riley v. California, the confiscation of a smartphone during a police raid was deemed to constitute a violation of the person who owned the phone, not simply a violation of that person's property.

Here the philosophy of mind can learn from the founding vision of the philosophy of technology. It was due to Ernst Kapp, a German émigré to Texas in the wake of the failed 1848 liberal revolutions that forced Marx to seek refuge in London. Once in America, Kapp was captivated by Ralph Waldo Emerson's characterisation of the telegraph as an extension of the human senses, an image that Marshall McLuhan popularised in the 1960 s to cover all media. To cut this part of the story short, what might be called The Strong Mind-Technology Thesis is that the philosophy of mind and the philosophy of technology are two ways of talking about the same thing, whereby 'technology' is understood to mean the mind's outworking in nature. From this standpoint, carbon and silicon are simply alternative natural elements out of which minds might be constituted, each with its own strengths and weaknesses as expressive media. [Kant's Critique of Judgement (1914) offered an early guide to this way of thinking about the matter.] To be sure, this still leaves open what it means to be human, especially the extent to which carbon and silicon need to be involved. Here the image of the cyborg stands for an acceptance of both, whereas the Linnaean equation is clearly carbon-biased. (Some might argue that mind-clones are silicon-biased.) Nevertheless, regardless of where one stands on this question, biology's role in determining the human is effectively neutralized.

Lurking behind Floridi's rearguard thinking is what in his and my youth was called 'folk psychology'. Earlier generations spoke of it as 'the manifest image of the world' or, more to point, 'common sense'. The purported function of folk psychology is to provide a sustainable reality for a certain conception of humanity, which is more or less defined by the Linnaean equation. This is what Peter Strawson (1959) famously called 'descriptive metaphysics'. Today, Strawson's use of 'descriptive' seems more polemical than he probably intended. Nevertheless, folk psychology is just as normative as any other way of accounting for being human. Indeed, any normative order turns on what constitutes a 'sustainable reality' for humans to exist. Nowadays we may understand this on at least three levels. The first is Strawson's own-namely, the conceptual presuppositions of the 'current' (i.e. as of the midtwentieth century) world, one in which humans exist as 'natural persons'. The second 
consists in the material conditions under which such beings might co-exist with other beings in the world, which is roughly the stuff of the Anthropocene. The third is in terms of the sort of being that can maximize the distinctiveness of being human within the confines of our energy capabilities. This conception, more ergonomic than ecological in spirit, favours the cyborg as Emerson anticipated-a carbonbased brain with indefinite silicon extensions that to varying degrees are attachable, replaceable and improvable. But as Riley v. California already suggests, this leaves open deep questions of the ontological jurisdiction of such beings in a world that is true to the principle that to be human is to be a value of the variable called 'human'.

Open Access This article is licensed under a Creative Commons Attribution 4.0 International License, which permits use, sharing, adaptation, distribution and reproduction in any medium or format, as long as you give appropriate credit to the original author(s) and the source, provide a link to the Creative Commons licence, and indicate if changes were made. The images or other third party material in this article are included in the article's Creative Commons licence, unless indicated otherwise in a credit line to the material. If material is not included in the article's Creative Commons licence and your intended use is not permitted by statutory regulation or exceeds the permitted use, you will need to obtain permission directly from the copyright holder. To view a copy of this licence, visit http://creativecommons.org/ licenses/by/4.0/.

\section{References}

Augustine (397-400). The Confessions. https://faculty.georgetown.edu/jod/augustine/textstrans.html. Accessed 6 March 2021.

Augustine (426). The City of God. http://www.archive.org/download/city_of_god_ds_librivox/city_of_ god_ds_librivox_64kb_mp3.zip. Accessed 6 March 2021.

Clark, A. (2004). Natural-Born Cyborgs: Minds, Technologies, and the Future of Human Intelligence. Cambridge, MA: MIT Press.

Clowes, R., Gärtner, K., \& Hipolito, I. (Eds.). (2021). Mind-Technology Problem: Investigating Minds, Selves and $21^{\text {st }}$ Century Artifacts. Berlin: Springer.

Darwin, C. (1866). On the Origin of Species. $4^{\text {th }}$ Edition. London: John Murray. http://darwin-online.org. uk/contents.html. Accessed 6 March 2021.

Floridi, L. (2014). The Fourth Revolution: How the Infosphere is Reshaping Human Reality. Oxford: Oxford University Press.

Fuller, S. (2019). Nietzschean Meditations: Untimely Thoughts at the Dawn of the Transhuman Era. Basel: Schwabe.

Kant, I. (1914). Critique of Judgement. Trans. J. H. Bernard. $2^{\text {nd }}$ Edition. London: Macmillan. https://oll. libertyfund.org/title/bernard-the-critique-of-judgement. Accessed 6 March 2021.

Linnaeus, C. (1759). System of Nature. https://www.biodiversitylibrary.org/item/10277\#page/4/mode/ 1up. Accessed 6 March 2021.

Lovejoy, A. (1936). The Great Chain of Being. Cambridge, MA: Harvard University Press.

Moore, G. E. (1903). Principia Ethica. http://fair-use.org/g-e-moore/principia-ethica. Accessed 6 March 2021.

Pinker, S. (2002). The Blank Slate. New York: Random House.

Quine, W. V. O. (1948). On What There Is. Review of Metaphysics, 2(5), 21-38.

Strawson, P. F. (1959). Individuals: An Essay in Descriptive Metaphysics. London: Methuen. 